ISSN 0258-7122 (Print), 2408-8293 (Online)

Bangladesh J. Agril. Res. 44(2): 203-221, June 2019

\title{
INTEGRATION OF MAIZE BETWEEN RICE AND WHEAT WITH SOIL AND NUTRIENT MANAGEMENT TO IMPROVE PRODUCTIVITY OF RICE-WHEAT CROPPING SYSTEM IN BANGLADESH
}

\author{
M. ATAUR RAHMAN ${ }^{1}$, M. A. ROUF ${ }^{2}$, K. M. F. HOSSAIN ${ }^{3}$ \\ M. B. RAHMAN ${ }^{4}$ AND M. A. WOHAB ${ }^{5}$
}

\begin{abstract}
The necessity of more food production from limited land enforced cropping intensification over-exploring the natural resources in Bangladesh. This field experiment was initiated to achieve improve and sustainable productivity of an intensive wheat-maize-rice cropping system with improved management of natural resources. Four levels of nutrient managements were tested under four soil management treatments starting with wheat crop sown in November 2009 and ending with the harvest of $8^{\text {th }}$ wheat crop in the system during March 2017. Yield and yield contributing characters of component crops and soil properties were studied following standard methods. Soil management treatment of rice straw mulch application in reduced till-bed or well-till flat soil upon wheat sowing was equally effective in conserving soil moisture, enhancing wheat root development, reducing weed growth and thereby positively influenced spikes $/ \mathrm{m}^{2}$ and finally wheat yield. Similarly, wheat straw mulch application contributed to ears $/ \mathrm{m}^{2}$ and grain yield of maize. Nutrient levels of recommended fertilizers plus $5.0 \mathrm{t} / \mathrm{ha}$ cowdung resulted in yield improvement of wheat and maize throughout the years. However, neither nutrient management nor soil management alone but the combination of recommended fertilizers with $5 \mathrm{t} / \mathrm{ha}$ cowdung couple with rice straw mulching in wheat and wheat straw mulching in maize resulted in maximum wheat and maize yield over the years. Rice yield was similar for different treatment combinations until the 4th cropping cycle and thereafter rice yield was also improved by the residual effect of straw mulches. Crop residue mulching along with addition of organic and inorganic fertilizers was found to be a promising soil management technology for achieving sustainable increased productivity of wheat-maize-rice system.
\end{abstract}

Keywords: Cropping intensification; Resource conservation; Straw mulch, Bed planting, Soil fertility; Sustainable system productivity.

\section{Introduction}

Scarcity of arable land with increasing food and nutrition demand for the growing population enforced the intensive cereal cultivation in Bangladesh. Generally, wheat crop in grown under wheat-fallow-rice and maize is grown under maize-fallow-rice cropping system in Bangladesh (Timsina and Connor,

\footnotetext{
${ }^{1-5}$ Research Wing, Bangladesh Agricultural Research Institute (BARI), Gazipur 1701, Bangladesh.
} 
2001). The integration of aforementioned two cropping systems shifting the maize crop from Rabi to Kharif season, could facilitate further intensification from existing double cropping system in to triple cropping system having the practical significance in increasing the cultivation areas of wheat and maize and thereby improve the system productivity (Rahman et al., 2013). But the intensive triple cereal system with the introduction of hybrid maize may cause exhaustion of soil nutrients and thus due attention is essential to maximize the productivity maintaining soil fertility at desired level with the intervention of conservation agricultural (CA) practice and nutrient management. The CA has been used over the last few years to distinguish the more sustainable agriculture from the narrowly-defined 'conservation tillage' and CA has the potentials in improving and sustaining system productivity (Gupta and Sayre, 2007; Wall et al., 2010). The yield of wheat and maize is lower at farm level than the achievable yield at research field due to sub-optimum fertilizer use and poor crop and soil management practices (Timsina et al., 2010; Gathala et al., 2011). Soil management through crop residue mulch ensures stand establishment, increase water use efficiency and reduce weed infestation and thereby improves wheat yield (Rahman et al., 2005). Recently integrated plant nutrient system (IPNS) based fertilization is advised to maximized productivity keeping the balance of soil fertility. Haque and Noor (2011) reported that soil test based fertilizer with organics $(\mathrm{STB}+5 \mathrm{t} / \mathrm{ha} \mathrm{CD})$ is superior in producing higher yield in maizemungbean-T. aman cropping pattern. Mulch contributes to carry over of residual soil moisture from one crop to another and thereby improve yield of wheat under reduced tillage (Sharma and Acharya, 2000). Reduced tillage especially sowing of wheat and maize by a single pass of power tiller operated seeder or bed planter is effective in saving time between wheat harvest and maize sowing in the intensive rice-wheat and rice-maize cropping systems (Jat et al., 2011) and the practice minimize production cost (Hossain et al., 2015) and saves irrigation water (Qureshi et al., 2015). Reduced tillage with crop residue retention is reported as efficient in resource utilization by wheat and maize crops (Govaerts et al., 2009). In most cases, the effects of either agronomic management or fertilizer management on rice-wheat and rice-maize systems or with the intervention of mung bean in the systems have been reported. Information on the intervention of maize in rice-wheat system integrating $\mathrm{CA}$ and nutrient management is scarce. Considering all these facts, the experiment was initiated to introduce maize in rice-wheat cropping system suggesting appropriate soil and nutrient management to achieve improved and sustainable system productivity and thereby contribute to food security of the country.

\section{Materials and Methods}

\section{a) Soil and Climate}

A fixed plot field study was conducted for the eight consecutive years from November 2009 to March 2017 at the research farm of the Bangladesh 
Agricultural Research Institute (BARI), Gazipur, Bangladesh (24 36'91" N latitude, $88^{\circ} 66^{\prime} 17^{\prime} \mathrm{E}$ longitude). The soil of research station belongs to Chiata series under Madhupur Tract (AEZ 28) characterized by clay texture and the area is flood free highland. The soil was deficient in organic matter, total $\mathrm{N}$ and most of the plant nutrients. The sub-surface soil $(15-30 \mathrm{~cm})$ was more deficient in different nutrients as compared to surface soil $(0-15 \mathrm{~cm})$. The initial soil $\mathrm{pH}$ of the experiment site was 6.5 at the surface and 6.7 at the sub-surface. The climate of the region is sub-tropical, with mean annual rainfall (1960-2015) is about 2000 $\mathrm{mm}$, of which $88 \%$ occurring during the rainy season (June-September). The wheat growing period (November to March) is fairly dry and the crops are exposed to higher temperature and water scarcity at reproductive to grain filling stages. The early growth period of maize is also dry but due to changes in climate some year monsoonal precipitation starts earlier and the maize crop faces double stress conditions of both drought and water logging (Fig 1 and Fig 2). The longterm mean rainfall, minimum and maximum temperature of the experimental site is presented in Figure 3.

\section{b) Experimental design and treatments}

The experiment comprised the combination of four levels of nutrient management and four levels of soil conservation practice (CA) tested in split plot design.

Nutrient management treatments assigned in main plots are:

1. Control (Native soil fertility)

2. Recommended rate of chemical fertilizers for all the component crops (RF),

3. Integrated plant nutrient system based fertilizers using $5 \mathrm{t} \mathrm{ha}^{-1}$ cow dung (IPNS) and

4. Recommended fertilizers plus $5 \mathrm{t} \mathrm{ha}^{-1}$ cow-dung (RF+CD).

Four CA treatments imposed in sub-plots are:

i) Bed - Sowing of wheat and maize seed in raised bed using power tiller operated bed planter.

ii) Bed+Mulch - Bed planting with rice straw mulching @ $3 \mathrm{t} \mathrm{ha}^{-1}$ before wheat and wheat straw mulching @ $3 \mathrm{tha}^{-1}$ before maize.

iii) Flat - Conventionally sowing of wheat and maize in well-tilled flat soil.

iv) Flat+Mulch -Sowing of wheat and maize in well-tilled flat soil and rice straw mulching as treatment 2.

\section{c) Crop varieties, plot size and cultural operation}

The size of each sub-plot was $5 \mathrm{~m} \mathrm{X} 2 \mathrm{~m}$ and there were gaps of 1.0, 1.5 and $1.5 \mathrm{~m}$ among the sub-plots, main plots and replications, respectively. Seeds of wheat 
variety Prodip were sown continuously in $20 \mathrm{~cm}$ spaced line at the rate of $120 \mathrm{~kg}$ $\mathrm{ha}^{-1}$ on $20^{\text {th }}$ November 2009. The variety Prodip was replaced by BARI Gom-26 in 2012-13 which was again replaced by BARI Gom-30 in 2015-16. In case of bed planting, after a pair of rows in bed there was a distance of $40 \mathrm{~cm}$ between border rows. Thus there were 4 beds in each sub-plot under bed planting that consisted 8 lines of wheat plants whereas in case of conventional the number of lines were 10 for each subplot. Fertilizers at the rates of $120 \mathrm{~kg} \mathrm{~N}, 30 \mathrm{~kg} \mathrm{P}, 50 \mathrm{~kg}$ $\mathrm{K}, 20 \mathrm{~kg} \mathrm{~S}$, and $1.5 \mathrm{~kg} \mathrm{~B} \mathrm{ha}^{-1}$ were applied as urea, triple super phosphate, murate of potash, gypsum, and boric acid, respectively as the RF for wheat. All fertilizers including two-thirds of urea were uniformly applied in the field during final land preparation. The rest of urea was top dressed at the crown root initiation (CRI) stage at 21 days after sowing (DAS). The crop was irrigated uniformly to bring the soil moisture near to field capacity during 20, 50 and 75 DAS. At maturity the wheat crop was harvested between first and second weeks of March then BARI Hybrid Maize-7 (2010 and 2011) and BARI Hybrid Maize9 (2012 to 2016) were sown in mid to end of March and then BINA Dhan-7 was transplanted following maize in mid-July. Fertilizers of $\mathrm{N}_{200} \mathrm{P}_{50} \mathrm{~K}_{100} \mathrm{~S}_{40} \mathrm{Zn}_{5} \mathrm{~B}_{2}$ and $\mathrm{N}_{80} \mathrm{P}_{30} \mathrm{~K}_{50} \mathrm{~S}_{20}$ were applied as recommended rate (RF) for maize and rice, respectively. After the harvest of wheat the experimental plots were prepared for maize seeding by conventional tillage in case of Flat and Flat+Mulch but in case of Bed and Bed+Mulch seeds were sown by opening a furrow between the two rows of wheat staple on the top of each bed and then the beds were reshaped manually. Wheat straw was used as mulch after sowing maize as per prescribed treatments. The rice crop was puddle transplanted for all the plots. Neither the crop residue nor the cowdung was used in rice crop. Again, during the sowing of second wheat crop, beds were prepared and treatments were imposed as in the first crop.

\section{d) Crop harvest and yield}

At maturity the crops were harvested from the whole sub-plots, sun dried and threshed plot wise. After threshing, the grains were sun dried and then moisture content of grain samples were determined. Grain yields were converted to $\mathrm{tha}^{-1}$ at $12 \%$ moisture content in case of wheat and maize and $14 \%$ moisture content in case of rice. Total biomass (grain + straw was weighed with a spring balance. Straw yields were recorded on air dry weight basis. Harvest Index (HI) was calculated as grain yield divided by total biomass yield on per hectare basis. All the data were statistically analyzed and the mean values were tested by the least significant difference (LSD) at $5 \%$ level of significance.

\section{Results and Discussion}

\section{A) Wheat yield}

Grain yield of wheat significantly responded to the nutrient levels for all the years. Nutrient level of $\mathrm{RF}+\mathrm{CD}$ resulted in highest grain yield ranging from 4.51 
t/ha during 2015-16 to 5.27 t/ha during 2012-13 (Table 5). Wheat yields under the treatment of IPNS were statistically similar to yields under the treatment of RF during the initial years until 2011-12 and thereafter IPNS resulted in significantly higher wheat yield over RF. The result indicated that only recommended chemical fertilizers are not enough to sustain wheat yield under the experimental soil condition. Theoretically the plots under IPNS and RF received the same amount of nutrients but a clear trend of better crop performance in IPNS compared to RF was observed from the $3^{\text {rd }}$ year which became dominant over the years (Table 5). A clear declining trend in yield was noticed under the treatment control; grain yield was drastically decreased from $3.0 \mathrm{t} / \mathrm{ha}$ in the $1^{\text {st }}$ year to less than $1.0 \mathrm{t} / \mathrm{ha}$ in the $8^{\text {th }}$ year. Grain yield of wheat is known to be interacted by many biotic and abiotic factors especially by the temperature and the spell of winter and thus wheat yield fluctuates year to year in Bangladesh (Timsina and Humphreys, 2006). In spite of the yearly fluctuation the treatment $\mathrm{RF}+\mathrm{CD}$ produced relatively stable higher yield over the years. Better crop performance under IPNS over RF and higher wheat yield under the treatment $\mathrm{RF}+\mathrm{CD}$ over IPNS indicated that only recommended dose of chemical fertilizers are not enough but application of extra fertilizers from organic sources were useful to sustain higher wheat production under the experimental cropping system and soil condition. Better performance of wheat under organic fertilizer added treatments (RF+CD and IPNS) may be due to the improvement of physical and biological properties in addition to the chemical property of soil which made the soil more productive. The result is consistent to the soil analysis report that suggested that most of the soil nutrients were declined with years in control plots whereas soil nutrient contents remained stable or even improved with years in the plots under the fertilizer treatment of RF+CD (Tables 2, 3 and 4).

Grain yield of wheat significantly responded to different soil management treatments throughout the study period (Table 5). Application of straw-mulch in beds resulted in significantly higher grain yield than beds without mulch. Similarly, straw-mulching in flat soil gave significantly higher yield compared to flat over the years (Table 5). Mulching reduces the evaporation loss of soil moisture and ensures availability of higher moisture and soil temperatures favorable for germination and stand establishment (Rahman et al., 2005). However, the yield under the treatments of Bed+Mulch was statistically similar to Flat+Mulch but higher then respective non-mulch treatments. The results demonstrate that mulch application either in bed or flat soil conditions were equally effective in improving soil condition as well as wheat yield as compared to respective non-mulch treatments. The wheat yield of eight years demonstrated that bed planting without crop residue mulch has no advantage over conventional flat with an exception in first year. Exception was found in the initial year, when bed gave higher wheat yield than conventional flat but resulted in statistically similar yields for the last seven years. Bed planting gave higher yield when straw mulch was applied on it. The initial soil moisture is considered as one of the most 
critical factors limiting the stand establishment of wheat. The wider interval periods between two successive irrigations in wheat caused serious soil moisture deficit affecting plant growth under fairly dry wheat growing period (Rahman et al., 2013). Rice straw mulch served as barrier of evaporative loss (Erenstien, 2002; Rahman et al., 2005) thus surface soil moisture in plots under Flat+Mulch and Bed+Mulch retained at optimum level that ensured optimum plant growth during the wide intervals of irrigations which finally contributed to higher grain yield under the treatments of Bed+Mulch and Flat+Mulch.

Table 1. Physical and chemical properties of the initial surface soil $(0-15 \mathrm{~cm})$ of the research field in November, 2009.

\section{a. Physical properties}

\begin{tabular}{c|c|c|c|c|c}
\hline $\begin{array}{c}\text { Bulk Density } \\
\left(\mathrm{g} \mathrm{cm}^{-3}\right)\end{array}$ & $\begin{array}{c}\text { Particle density } \\
\left(\mathrm{g} \mathrm{cm}^{-3}\right)\end{array}$ & $\begin{array}{c}\text { Porosity } \\
(\%)\end{array}$ & $\begin{array}{c}\text { Soil moisture } \\
\text { at wheat } \\
\text { sowing }(\%)\end{array}$ & $\begin{array}{c}\text { Field capacity } \\
(\%)\end{array}$ & Textural class \\
\hline 1.52 & 2.46 & 38.22 & 20.18 & 29.12 & $\begin{array}{c}\text { Silty Clay- } \\
\text { Loam }\end{array}$ \\
\hline
\end{tabular}

\section{b. Chemical properties}

\begin{tabular}{c|c|c|c|c|c|c|c|c|c|c|c|c|c}
\hline $\begin{array}{c}\text { Soil } \\
(0-15 \mathrm{~cm})\end{array}$ & $\mathrm{pH}$ & $\begin{array}{c}\text { OM } \\
(\%)\end{array}$ & $\begin{array}{c}\text { Total } \\
\mathrm{N} \\
(\%)\end{array}$ & $\mathrm{P}$ & $\mathrm{S}$ & $\mathrm{B}$ & $\mathrm{Zn}$ & $\mathrm{Cu}$ & $\mathrm{Fe}$ & $\mathrm{Mn}$ & $\mathrm{K}$ & $\mathrm{Ca}$ & $\mathrm{Mg}$ \\
\hline Initial & 6.4 & 0.97 & 0.06 & 13.5 & 16 & 0.17 & 1.8 & 3.1 & 108 & 16 & 0.09 & 5.5 & 2.4 \\
\hline \multicolumn{1}{c|}{ Critical level } & - & - & 7.0 & 14 & 0.20 & 2.0 & 1.0 & 10.0 & 5.0 & 0.20 & 2.0 & 0.8 \\
\hline
\end{tabular}

\section{c. Nutrient status of cowdung used in the experimental field}

\begin{tabular}{c|c|c|c|c|c|c|c|c|c|c|c|c|c}
\hline $\begin{array}{c}\text { Name of } \\
\text { the } \\
\text { manure }\end{array}$ & $\mathrm{pH}$ & $\mathrm{OM}$ & $\begin{array}{c}\text { Total } \\
\mathrm{N}\end{array}$ & $\mathrm{K}$ & $\mathrm{Ca}$ & $\mathrm{Mg}$ & $\mathrm{P}$ & $\mathrm{S}$ & $\mathrm{B}$ & $\mathrm{Zn}$ & $\mathrm{Pb}$ & $\mathrm{Cd}$ \\
\cline { 2 - 12 } & \multicolumn{7}{|c|}{$(\%)$} \\
\hline $\begin{array}{c}\text { Cow dung } \\
(2009-10)\end{array}$ & 7.6 & 12.1 & 1.12 & 0.53 & 1.75 & 0.54 & 1.23 & 0.38 & 0.013 & 0.15 & 2.30 & 2.48 \\
\hline $\begin{array}{c}\text { Cow dung } \\
(2011-12)\end{array}$ & 7.4 & 8.8 & 0.78 & 0.67 & 1.55 & 0.44 & 0.88 & 0.26 & 0.012 & 0.17 & 2.86 & 2.12 \\
\hline $\begin{array}{c}\text { Cow dung } \\
(2013-14)\end{array}$ & 7.5 & 9.1 & 0.82 & 0.64 & 1.60 & 0.47 & 0.92 & 0.33 & 0.011 & 0.15 & 2.42 & 2.05 \\
\hline $\begin{array}{c}\text { Cow } \\
\text { dung } \\
(2015-16)\end{array}$ & 7.6 & 11.7 & 1.08 & 0.63 & 1.67 & 0.51 & 1.17 & 0.35 & 0.017 & 0.16 & 2.23 & 2.24 \\
\hline
\end{tabular}

The interaction effect of nutrient and soil management levels on grain yield of wheat was significant for all the years with an exception in 2011-12. The treatments Bed and Flat planting resulted in statistically similar wheat yield under any level of nutrients in the main plots. Similarly, Bed+Mulch and 
Flat+Mulch resulted in statistically similar grain yield under any nutrient level those were higher than respective non-mulch treatments. Straw mulching was effective in improving wheat yield as compared to respective non-mulch treatment throughout the experimental period. However, this mulching effect was significant up to initial four years for all the nutrient levels. Thereafter, deviations were found; under control wheat yield drastically declined and difference between mulch and non-mulch treatment became non-significant from $5^{\text {th }}$ year to onwards. But under the nutrient level of RF and IPNS, mulching effect remained significantly superior throughout the experimental periods. Again $\mathrm{RF}+\mathrm{CD}$, the mulching effect became confounded in later years thus yield advantage in Bed+Mulch over Bed and yield advantage in Flat+Mulch over Flat became nonsignificant from the $6^{\text {th }}$ year. In RF+CD treatment, cowdung was applied @ 5 $\mathrm{t} / \mathrm{ha}$ twice a year with recommended fertilizers in each crops thus the treatment $\mathrm{RF}+\mathrm{CD}$ had brought the soil fertility and soil physical condition so favorable (Tables 2 and 3) that crop performance became statistically similar whether straw mulch applied or not. However, the maximum wheat yield was achieved due to combined effect of RF+CD in main plots with Bed+Mulch or Flat+Mulch in the sub plots in all the years. The yield of wheat for the eight years effectively demonstrated that mulch application either in Bed or in Flat had the potentials in retaining soil moister and overcoming moisture stress to some extend that might have led to better crop yield (Fig. 2).

\section{B) Maize yield}

The main effect of nutrients and soil management as well as their interactions on grain yield of maize were significant (Table 6). Nutrient levels of RF+CD gave the maximum maize yield followed by IPNS and RF. The treatment IPNS and RF produced statistically similar yield in initial 4 years and thereafter, from $5^{\text {th }}$ year the treatment $\mathrm{RF}+\mathrm{CD}$ produced higher yield over IPNS and again IPNS produced higher yield over RF. The result indicated that maize crop is responsive to higher dose of fertilizer when grown under intensive wheat-maize-rice system. IPNS plots received the same amount of nutrients as in RF but the other benefit of added cow-dung in IPNS plots for the several years resulted in better soil quality (Table 2, 3 and 4) that favored to produce better yield in IPNS treatment compared to RF treatment.

Among the soil management treatments, Flat+Mulch gave higher yield than Flat and similarly Bed+Mulch performed better yield than Bed throughout the study period. The treatment Flat+Mulch and Bed+Mulch were equally effective in improving grain yield of maize. Again, interactions of fertilizer levels and soil management treatments had significant effect on grain yield of maize. This year, the combination of $\mathrm{RF}+\mathrm{CD}$ and Flat+Mulch resulted in maximum maize yield $(7.36 \mathrm{t} / \mathrm{ha})$ that was statistically similar to the yield grain yield obtained from treatment combination of $\mathrm{RF}+\mathrm{CD}$ and Bed +Mulch. In the remaining years, similar result of better yield performance was noted in Flat+Mulch with 


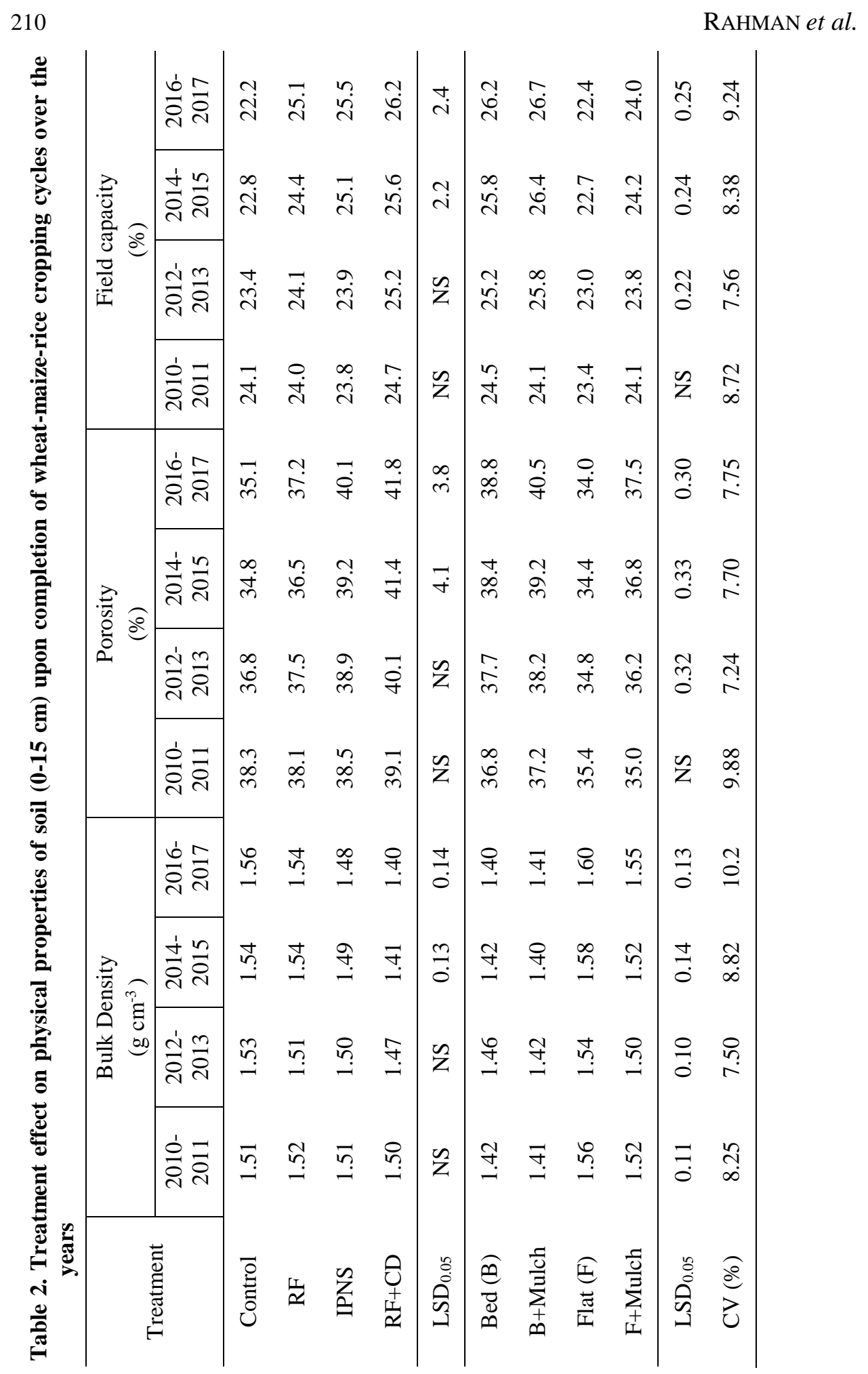


INTEGRATION OF MAIZE BETWEEN RICE AND WHEAT WITH SOIL

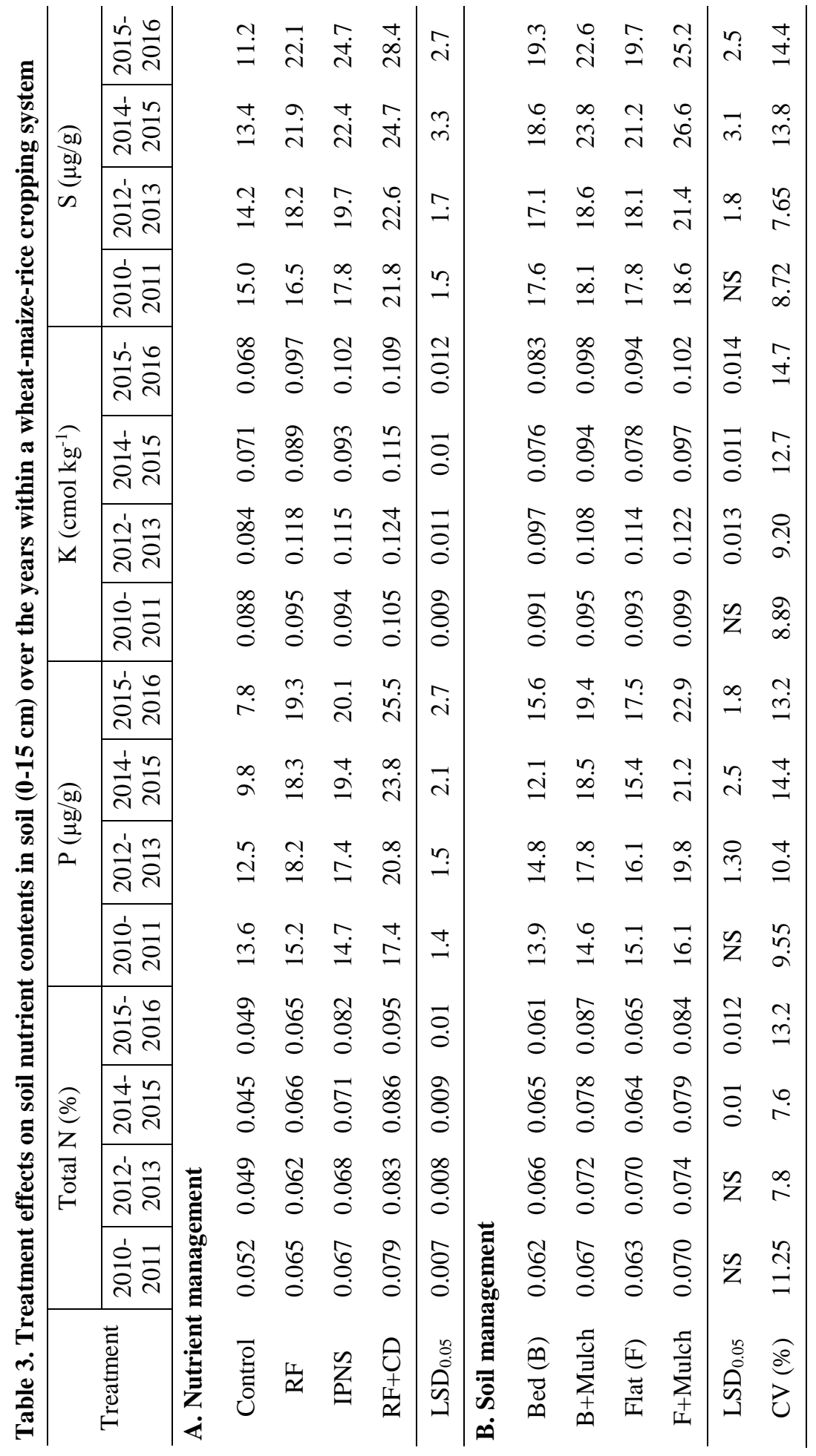




\begin{tabular}{|c|c|c|c|c|c|c|c|c|c|c|c|c|c|c|}
\hline \multirow{4}{*}{ 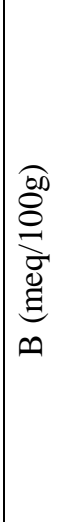 } & 光 & & & ֶָ) & $\stackrel{\substack{n \\
0}}{0}$ & $\overbrace{0}^{n}$ & $\stackrel{8}{0}$ & & $\overline{\widetilde{o}}$ & సે & กิ & $\stackrel{m}{0}$ & $\stackrel{0}{0}$ & $\bar{\Xi}$ \\
\hline & $\stackrel{+}{\stackrel{1}{\circ}} \frac{n}{0}$ & & $\frac{1}{0}$ & त̄ & 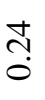 & $\stackrel{m}{0}$ & $\stackrel{t}{0}$ & & $\stackrel{\infty}{\circ}$ & $\stackrel{m}{0}$ & $\vec{\jmath}$ & $\stackrel{\sim}{0}$ & $\stackrel{\circ}{\circ}$ & $\stackrel{\infty}{=}$ \\
\hline & 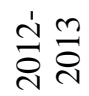 & & $\stackrel{0}{0}$ & 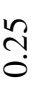 & 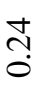 & ஸే & $\stackrel{n}{0}$ & & $\tilde{\widetilde{o}}$ & ल] & $\stackrel{\overbrace{}}{0}$ & $\stackrel{\infty}{\stackrel{\infty}{0}}$ & $\stackrel{n}{0}$ & $\stackrel{+}{\infty}$ \\
\hline & 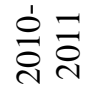 & & $\frac{9}{0}$ & ণิ & $\vec{ָ}$ & กิ & $\tilde{z}$ & & $\frac{\infty}{0}$ & ஸి & $\frac{9}{0}$ & $\widehat{\widehat{o}}$ & $\stackrel{+}{0}$ & $\stackrel{r}{r}$ \\
\hline \multirow{4}{*}{$\begin{array}{l}\frac{200}{200} \\
\frac{20}{3} \\
\text { N }\end{array}$} & $\stackrel{1}{n} \frac{0}{\delta}$ & & $\underset{.}{\stackrel{+}{~}}$ & $\frac{\infty}{i}$ & त̂ & $\underset{\sim}{\text { f }}$ & $\stackrel{\text { đ̦ }}{0}$ & & $\underset{i}{\stackrel{O}{i}}$ & $\underset{\mathrm{N}}{\stackrel{J}{N}}$ & $\underset{\sim}{\stackrel{0}{i}}$ & 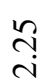 & $\tilde{z}$ & $\begin{array}{l}\infty \\
\stackrel{\sim}{\sim}\end{array}$ \\
\hline & 遂 $\frac{n}{8}$ & & & $\stackrel{\infty}{\leftrightarrow}$ & $\widehat{\sigma}$ & $\underset{i}{\stackrel{\Delta}{i}}$ & ণิ & & $\stackrel{શ}{\exists}$ & $\begin{array}{l}b \\
i\end{array}$ &  & $\underset{\mathrm{i}}{\mathrm{i}}$ & $\overrightarrow{\widetilde{o}}$ & $\stackrel{n}{ \pm}$ \\
\hline & 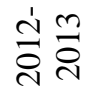 & & & $\underset{i}{\stackrel{t}{i}}$ & $\stackrel{\leftrightarrow}{\sigma}$ & $\underset{\text { ¿ }}{\text { i }}$ & $\tilde{z}$ & & $\stackrel{\text { ळे }}{\text {. }}$ & $\underset{i}{\stackrel{\infty}{i}}$ & $\stackrel{+}{\sigma}$ & $\underset{\text { d̦ }}{\text { id }}$ & $\bar{z}$ & $\stackrel{\overbrace{}}{\varrho}$ \\
\hline & 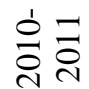 & & 足 & $\stackrel{n}{2}$ & $\stackrel{\overbrace{}}{\stackrel{i}{0}}$ & $\stackrel{\overbrace{}}{\sim}$ & ָ̦ & & $\tilde{g}$ & $\hat{a}$ & $\stackrel{\infty}{\infty}$ & $\underset{\text { d }}{\stackrel{+}{ }}$ & $\tilde{z}$ & $\underset{\infty}{\infty}$ \\
\hline \multirow{4}{*}{$\frac{\widehat{o}}{\sum_{0}}$} & $\stackrel{n}{\circ}$ & & 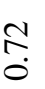 & ָ̃ & 喵 & $\stackrel{\infty}{\stackrel{\sim}{\sim}}$ & $\stackrel{1}{\circ}$ & & $\stackrel{\overbrace{}}{\stackrel{n}{\sim}}$ & $\stackrel{\text { q }}{\text {. }}$ & $\underset{-}{ \pm}$ & $\stackrel{n}{n}$ & $=$ & $\stackrel{+}{\mathrm{I}}$ \\
\hline & $\stackrel{+}{\dot{d}} \frac{n}{\stackrel{i}{c}}$ & & $\begin{array}{l}\infty \\
\infty \\
0\end{array}$ &  & ले & $\stackrel{t}{0}$ & $\stackrel{m}{0}$ & & $\stackrel{\overbrace{}}{-}$ & $\stackrel{n}{n}$ & $\stackrel{\infty}{\rightleftarrows}$ & $\underset{-}{\exists}$ & $\stackrel{ \pm}{0}$ & $\stackrel{\infty}{\stackrel{\Xi}{ \pm}}$ \\
\hline & 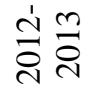 & & $\bar{\sigma}$ & $\stackrel{8}{g}$ & $\stackrel{\overbrace{}}{(}$ & $\stackrel{F}{ت}$ & $\overrightarrow{0}$ & & $\stackrel{0}{\circ}$ & $\stackrel{9}{\leftrightarrows}$ & $\stackrel{\sim}{\leftrightarrows}$ & $\stackrel{\infty}{\stackrel{\infty}{\longrightarrow}}$ & $\frac{1}{0}$ & $\begin{array}{l}8 \\
\stackrel{8}{0}\end{array}$ \\
\hline & 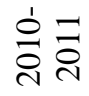 & 馬 & $\mathfrak{o}$ & $\Xi$ & $\stackrel{\overbrace{}}{\rightarrow}$ & $\stackrel{\overbrace{}}{-}$ & & $\vec{\Xi}$ & $\stackrel{m}{=}$ & $\stackrel{\infty}{=}$ & $\stackrel{ \pm}{\beth}$ & $\stackrel{\vartheta}{=}$ & $\bar{z}$ &  \\
\hline & 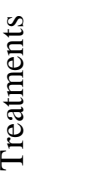 & 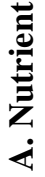 & 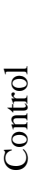 & II & $z$ &  & $\begin{array}{l}\stackrel{0}{0} \\
\stackrel{\tilde{\sigma}}{\Theta}\end{array}$ & 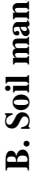 & $\widehat{\vartheta}$ & 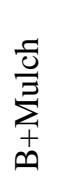 & $\begin{array}{l}\widetilde{E} \\
\stackrel{\Xi}{E}\end{array}$ & 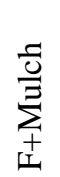 & $\stackrel{\tilde{0}}{\stackrel{0}{0}}$ & $\frac{d}{2}$ \\
\hline
\end{tabular}


few exceptions in 2010 and 2015 when higher yield was found in Bed+Mulch. However, in all the years the grain yield of maize was statistically similar for Bed+Mulch and Flat+Mulch (Table 6). Under any level of nutrients, the soil management treatments of Flat and Bed produced statistically similar yields and those were significantly improved by mulch application both on the bed and on flat (Bed+Mulch or Flat+Mulch). The soil management practices of Flat+Mulch and Bed+Mulch improved the physical properties of the soil (Table 2) that improved soil moisture conservation during the dry period before irrigation (Fig. 2). Again during the wet season, the same couple of soil management treatment ensured better drainage thus the crop escape from water logging condition (Fig. 2).
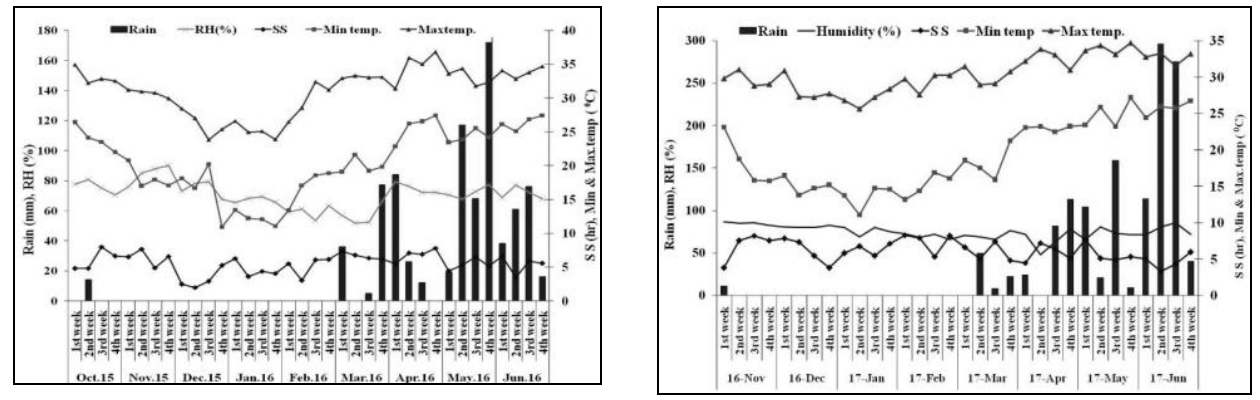

Fig. 1: Seasonal and yearly variation in rainfall, maximum, minimum temperatures, humidity and sunshine hour at the experiment site.

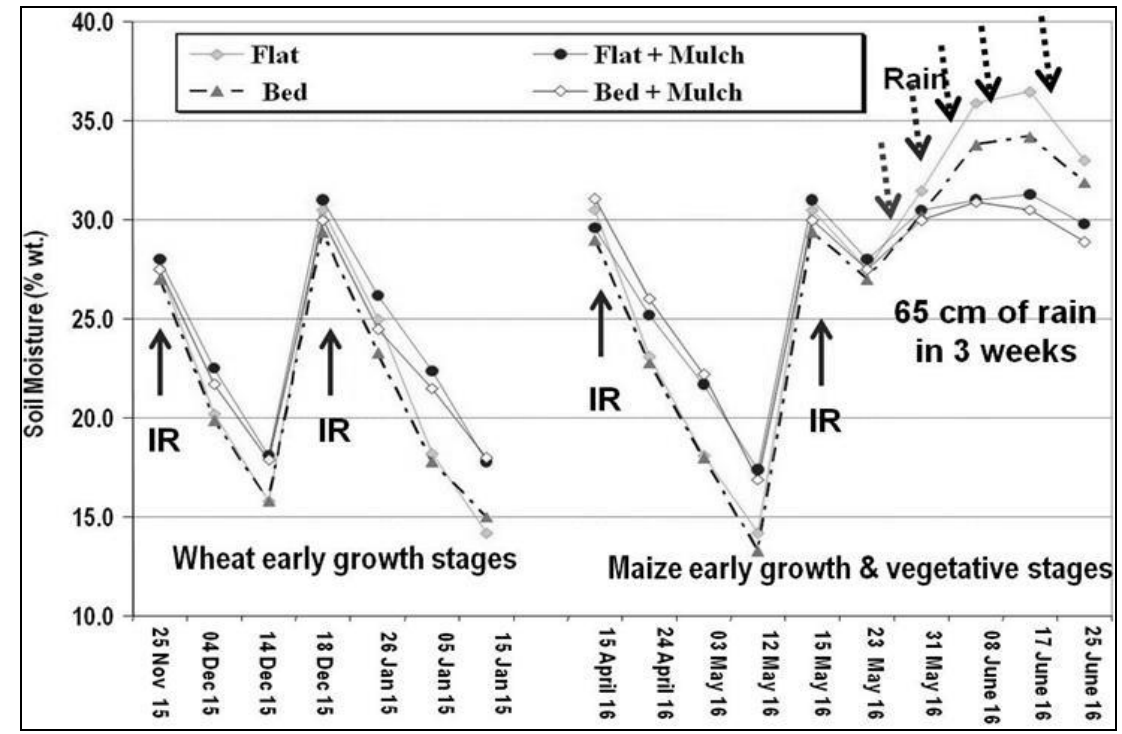

Fig. 2: Seasonal variation in soil moisture due to irrigation and rainfall as influenced by Soil Management (Conservation) treatments. 


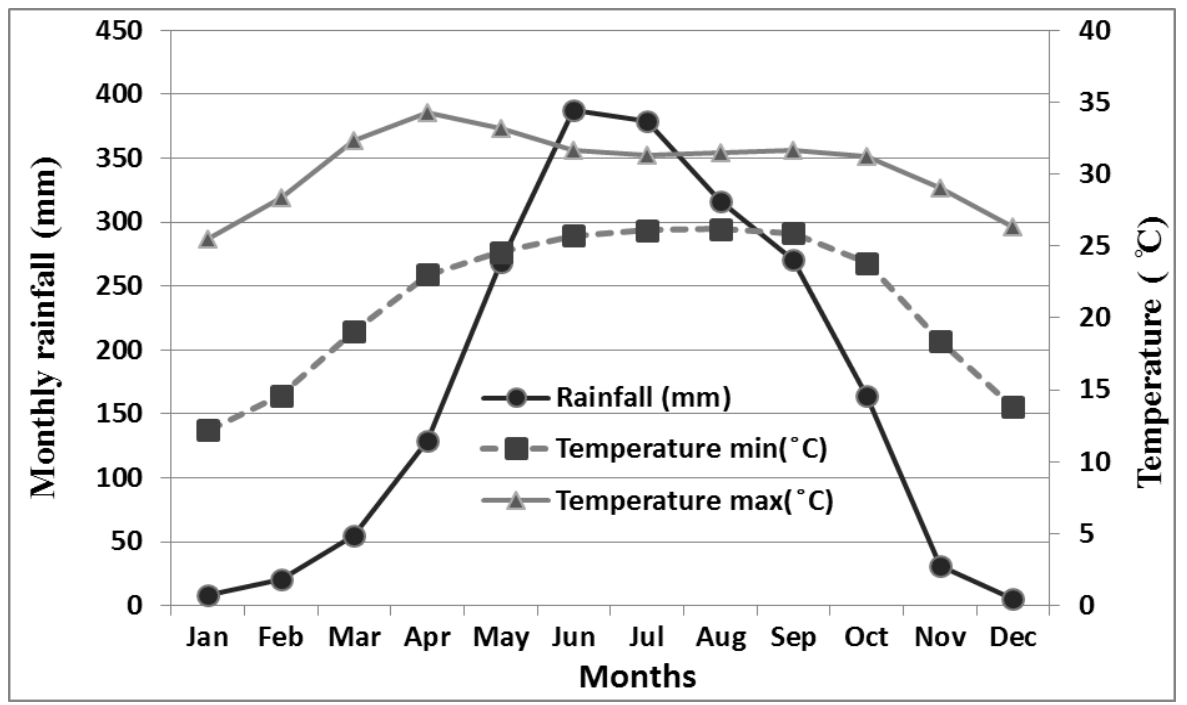

Fig. 3: Mean (1960-2016) rainfall, maximum and minimum temperatures of the experiment site.

Under control, mulch application on bed or mulch application on flat had significant yield advantages up to initial three years. Thereafter yield difference between mulch and non-mulch treatment became non-significant. Under control (Native soil fertility) condition maize yield drastically declined with years and mulch application alone could not contribute to sustain higher yield. But under the nutrient levels of RF, IPNS and RF+CD mulch application either on bed or flat had significant yield advantages over respective non-mulch treatments throughout the years. The maize crop grown in Kharif-1 season suffered from water stress during the early growth period (Fig. 2). Application of mulch either in bed or in flat was effective in conserving soil moisture that contributed to stand establishment and finally yield of maize. Similar benefit of mulch was described by Rahman et al. (2016) under saline soil condition.

Table 5. Effect of soil and nutrient managements and their interactions on grain yield $(t / h a)$ of wheat within a wheat-maize-rice cropping system over the years

\begin{tabular}{l|l|l|l|l|l|l|l|l}
\hline Treatment & $2009-10$ & $2010-11$ & $2011-12$ & $2012-13$ & $2013-14$ & $2014-15$ & $2015-16$ & $2016-17$ \\
\hline
\end{tabular}

\begin{tabular}{lllllllll}
\hline A. Nutrient management & & & & & & \\
Control & 3.03 & 2.05 & 1.76 & 1.54 & 1.32 & 1.28 & 1.05 & 0.97 \\
RF & 4.83 & 4.44 & 3.80 & 4.60 & 4.30 & 3.86 & 3.62 & 3.88 \\
IPNS & 5.06 & 4.59 & 4.10 & 4.83 & 4.62 & 4.22 & 4.02 & 4.32 \\
RF+5t CD & 5.31 & 5.13 & 4.37 & 5.27 & 5.10 & 4.54 & 4.51 & 4.68 \\
\hline
\end{tabular}


Table 5. Cont'd

\begin{tabular}{l|c|c|c|c|c|c|c|c}
\hline \multicolumn{1}{c|}{ Treatment } & $2009-10$ & $2010-11$ & $2011-12$ & $2012-13$ & $2013-14$ & $2014-15$ & $2015-16$ & $2016-17$ \\
\hline \multicolumn{7}{l}{ B. Soil Management } \\
Bed & 4.34 & 3.91 & 3.15 & 3.83 & 3.56 & 3.22 & 3.06 & 3.12 \\
Bed+Mulch & 4.76 & 4.41 & 3.68 & 4.36 & 3.98 & 3.66 & 3.46 & 3.85 \\
Flat & 4.39 & 3.76 & 3.34 & 3.78 & 3.69 & 3.26 & 3.13 & 3.45 \\
Flat+Mulch & 4.74 & 4.12 & 3.75 & 4.27 & 4.10 & 3.77 & 3.56 & 3.98 \\
\hline
\end{tabular}

\section{Interaction}

Control $\times$

$\begin{array}{lllllllll}\text { Bed (B) } & 2.72 & 1.80 & 1.54 & 1.35 & 1.12 & 1.10 & 0.92 & 0.88 \\ \text { B +Mulch } & 3.26 & 2.54 & 1.75 & 1.87 & 1.48 & 1.47 & 1.23 & 1.14 \\ \text { Flat (F) } & 2.88 & 1.70 & 1.68 & 1.26 & 1.25 & 1.05 & 0.88 & 0.93 \\ \text { F+Mulch } & 3.28 & 2.16 & 2.06 & 1.66 & 1.41 & 1.52 & 1.25 & 1.23\end{array}$

$\boldsymbol{R F} \times$

\begin{tabular}{lcccccccc} 
Bed (B) & 4.62 & 4.13 & 3.56 & 4.44 & 4.08 & 3.41 & 3.39 & 3.55 \\
B +Mulch & 4.88 & 4.81 & 4.05 & 4.98 & 4.42 & 4.17 & 3.74 & 4.05 \\
Flat (F) & 4.71 & 4.32 & 3.43 & 4.28 & 4.11 & 3.59 & 3.44 & 3.67 \\
F+Mulch & 5.13 & 4.48 & 4.16 & 4.71 & 4.57 & 4.28 & 3.87 & 4.24 \\
IPNS $\times$ & & & & & & & & \\
Bed (B) & 4.94 & 4.47 & 3.40 & 4.54 & 4.40 & 3.88 & 3.56 & 4.09 \\
B +Mulch & 5.24 & 4.87 & 4.32 & 5.12 & 4.85 & 4.47 & 4.28 & 4.50 \\
Flat (F) & 4.78 & 4.14 & 4.09 & 4.46 & 4.25 & 3.97 & 3.84 & 4.12 \\
F+Mulch & 5.29 & 4.86 & 4.39 & 5.19 & 4.88 & 4.51 & 4.38 & 4.58 \\
RF+CD $\times$ & & & & & & & & \\
Bed (B) & 5.12 & 5.02 & 4.11 & 4.98 & 4.62 & 4.45 & 4.38 & 4.28 \\
B +Mulch & 5.67 & 5.43 & 4.58 & 5.45 & 5.15 & 4.52 & 4.60 & 4.66 \\
Flat (F) & 5.21 & 4.85 & 4.19 & 5.12 & 5.13 & 4.41 & 4.42 & 4.45 \\
F+Mulch & 5.22 & 5.01 & 4.57 & 5.51 & 5.52 & 4.78 & 4.64 & 4.71 \\
\hline LSD (0.05) & & & & & & & & \\
A) Nutriment & 0.34 & 0.49 & 0.31 & 0.54 & 0.44 & 0.40 & 0.35 & 0.39 \\
B) Soil Mag. & 0.31 & 0.40 & 0.26 & 0.43 & 0.41 & 0.38 & 0.33 & 0.41 \\
C) Interaction & 0.39 & 0.47 & NS & 0.48 & 0.47 & 0.42 & 0.40 & 0.44 \\
CV (\%) & 7.5 & 8.3 & 8.5 & 9.2 & 8.5 & 8.2 & 9.3 & 8.7 \\
\hline & & & & & & & & \\
\hline
\end{tabular}


Table 6. Effect of soil and nutrient managements and their interactions on grain yield ( $t / h a)$ of maize within a wheat-maize-rice cropping system over the years

\begin{tabular}{|c|c|c|c|c|c|c|c|}
\hline Treatment & 2010 & 2011 & 2012 & 2013 & 2014 & 2015 & 2016 \\
\hline \multicolumn{8}{|c|}{ A. Nutrient management } \\
\hline Control & 2.06 & 1.81 & 1.47 & 1.14 & 1.04 & 0.76 & 0.61 \\
\hline $\mathrm{RF}$ & 6.75 & 6.62 & 6.97 & 6.54 & 5.75 & 6.24 & 5.75 \\
\hline IPNS & 6.25 & 6.88 & 7.11 & 7.29 & 6.21 & 6.85 & 6.72 \\
\hline $\mathrm{RF}+5 \mathrm{t} \mathrm{CD}$ & 7.03 & 7.34 & 7.98 & 8.13 & 6.48 & 7.12 & 7.38 \\
\hline \multicolumn{8}{|c|}{ B. Soil Management } \\
\hline Bed & 5.38 & 5.57 & 5.74 & 5.72 & 4.67 & 5.29 & 5.12 \\
\hline Bed+Mulch & 6.05 & 6.36 & 6.41 & 6.48 & 5.65 & 6.41 & 6.55 \\
\hline Flat & 5.54 & 5.27 & 5.15 & 5.28 & 4.92 & 5.27 & 5.38 \\
\hline Flat+Mulch & 5.94 & 6.24 & 6.72 & 6.91 & 5.84 & 6.75 & 6.88 \\
\hline \multicolumn{8}{|c|}{ C. Interaction } \\
\hline \multicolumn{8}{|l|}{ Control $\times$} \\
\hline Bed (B) & 1.74 & 1.28 & 1.04 & 0.95 & 0.82 & 0.61 & 0.54 \\
\hline B +Mulch & 2.44 & 1.51 & 1.42 & 1.35 & 1.22 & 0.89 & 0.76 \\
\hline Flat (F) & 1.87 & 1.28 & 1.10 & 0.92 & 0.88 & 0.74 & 0.60 \\
\hline F+Mulch & 2.31 & 1.90 & 1.52 & 1.48 & 1.22 & 0.85 & 0.78 \\
\hline \multicolumn{8}{|l|}{$R F \times$} \\
\hline Bed (B) & 6.27 & 6.20 & 6.47 & 6.55 & 5.48 & 6.15 & 6.08 \\
\hline B +Mulch & 6.72 & 6.96 & 7.18 & 6.98 & 6.12 & 6.52 & 6.60 \\
\hline Flat (F) & 5.95 & 6.11 & 6.04 & 6.20 & 5.54 & 6.88 & 6.46 \\
\hline F+Mulch & 6.47 & 7.04 & 7.22 & 6.74 & 6.06 & 7.13 & 7.38 \\
\hline \multicolumn{8}{|l|}{$I P N S \times$} \\
\hline Bed (B) & 6.17 & 6.32 & 6.55 & 6.72 & 5.76 & 5.41 & 5.68 \\
\hline B +Mulch & 6.55 & 6.86 & 7.32 & 7.27 & 6.26 & 5.78 & 6.84 \\
\hline Flat (F) & 5.86 & 6.11 & 6.28 & 6.42 & 5.64 & 6.68 & 6.34 \\
\hline F+Mulch & 6.18 & 7.15 & 7.75 & 7.66 & 6.37 & 7.63 & 7.18 \\
\hline \multicolumn{8}{|l|}{$R F+C D \times$} \\
\hline Bed (B) & 6.24 & 6.77 & 7.15 & 7.65 & 6.02 & 7.21 & 7.68 \\
\hline B +Mulch & 7.06 & 7.45 & 7.87 & 8.12 & 6.38 & 7.83 & 7.67 \\
\hline Flat (F) & 6.57 & 6.74 & 7.13 & 7.45 & 5.98 & 7.14 & 7.82 \\
\hline F+Mulch & 7.37 & 7.66 & 8.02 & 8.28 & 6.42 & 8.05 & 8.16 \\
\hline
\end{tabular}


Table 6. Cont'd

\begin{tabular}{lcc|c|c|c|c|c}
\hline Treatment & 2010 & 2011 & 2012 & 2013 & 2014 & 2015 & 2016 \\
\hline $\begin{array}{l}\text { LSD (0.05) } \\
\text { A) Nutrients }\end{array}$ & 0.71 & 0.67 & 0.70 & 0.42 & 0.47 & 0.43 & 0.47 \\
$\begin{array}{l}\text { B) Soil } \\
\quad \text { Management }\end{array}$ & 0.63 & 0.58 & 0.56 & 0.38 & 0.44 & 0.34 & 0.44 \\
C) Interaction & 0.78 & 0.72 & 0.64 & 0.45 & 0.42 & 0.41 & 0.42 \\
CV $(\%)$ & 10.3 & 9.8 & 7.7 & 7.2 & 8.1 & 7.6 & 9.8 \\
\hline
\end{tabular}

Table 7. Effect of soil and nutrient managements and their interactions on grain yield (t/ha) of rice within a wheat-maize-rice cropping system over the years

\begin{tabular}{|c|c|c|c|c|c|c|c|}
\hline Treatment & 2010 & 2011 & 2012 & 2013 & 2014 & 2015 & 2016 \\
\hline \multicolumn{8}{|c|}{ A. Nutrient management } \\
\hline Control & 2.98 & 2.85 & 3.02 & 2.91 & 2.98 & 3.14 & 3.04 \\
\hline $\mathrm{RF}$ & 4.34 & 4.21 & 4.41 & 4.48 & 5.07 & 5.05 & 5.01 \\
\hline IPNS & 4.58 & 4.50 & 4.81 & 4.95 & 5.44 & 5.64 & 5.49 \\
\hline $\mathrm{RF}+5 \mathrm{t} \mathrm{CD}$ & 4.32 & 3.94 & 4.28 & 4.38 & 4.97 & 4.91 & 4.71 \\
\hline \multicolumn{8}{|c|}{ B. Soil Management } \\
\hline Bed & 3.91 & 3.85 & 4.01 & 4.04 & 4.41 & 4.38 & 4.32 \\
\hline Bed+Mulch & 4.12 & 3.83 & 4.11 & 4.29 & 4.94 & 4.88 & 4.74 \\
\hline Flat & 3.80 & 3.92 & 4.22 & 4.12 & 4.24 & 4.41 & 4.36 \\
\hline Flat+Mulch & 4.18 & 3.90 & 4.21 & 4.29 & 4.82 & 5.02 & 4.84 \\
\hline \multicolumn{8}{|c|}{ C. Interaction } \\
\hline \multicolumn{8}{|c|}{ Controlx } \\
\hline Bed (B) & 2.58 & 2.83 & 3.11 & 2.94 & 2.82 & 2.87 & 2.78 \\
\hline B +Mulch & 3.31 & 2.77 & 3.03 & 3.10 & 3.22 & 3.38 & 3.21 \\
\hline Flat (F) & 2.20 & 3.02 & 3.12 & 2.85 & 2.68 & 2.75 & 2.85 \\
\hline F+Mulch & 3.05 & 2.76 & 2.95 & 2.87 & 3.18 & 3.56 & 3.30 \\
\hline \multicolumn{8}{|l|}{$R F \times$} \\
\hline Bed (B) & 4.28 & 4.10 & 4.23 & 4.35 & 4.83 & 4.84 & 4.78 \\
\hline B +Mulch & 4.42 & 4.22 & 4.36 & 4.42 & 5.53 & 5.35 & 5.34 \\
\hline Flat (F) & 4.19 & 4.16 & 4.58 & 4.60 & 4.52 & 4.72 & 4.65 \\
\hline F+Mulch & 4.47 & 4.35 & 4.45 & 4.55 & 5.25 & 5.27 & 5.26 \\
\hline
\end{tabular}


Table 7. Cont'd

\begin{tabular}{l|c|c|c|c|c|c|c}
\hline Treatment & 2010 & 2011 & 2012 & 2013 & 2014 & 2015 & 2016 \\
\hline IPNS $\times$ & & & & & & \\
Bed (B) & 4.45 & 4.40 & 4.45 & 4.52 & 5.18 & 5.26 & 5.18 \\
B +Mulch & 4.65 & 4.41 & 4.94 & 5.24 & 5.85 & 5.72 & 5.66 \\
Flat (F) & 4.11 & 4.47 & 4.72 & 4.65 & 4.96 & 5.34 & 5.24 \\
F+Mulch & 4.82 & 4.72 & 5.10 & 5.38 & 5.80 & 6.04 & 5.86 \\
$\boldsymbol{R F}+\boldsymbol{C D} \times$ & & & & & & & \\
Bed (B) & 4.21 & 4.05 & 4.25 & 4.33 & 4.82 & 4.69 & 4.52 \\
B +Mulch & 4.43 & 3.92 & 4.12 & 4.38 & 5.15 & 5.05 & 4.75 \\
Flat (F) & 4.21 & 4.02 & 4.46 & 4.36 & 4.80 & 4.88 & 4.68 \\
F+Mulch & 4.40 & 3.78 & 4.33 & 4.45 & 5.06 & 5.11 & 4.86 \\
\hline LSD (0.05) & & & & & & & \\
A) Nutrients & 0.42 & 0.47 & 0.51 & 0.41 & 0.40 & 0.51 & 0.42 \\
B) Soil Mang. & NS & NS & NS & NS & 0.42 & 0.38 & 0.40 \\
C) Interaction & 0.48 & NS & 0.42 & 0.46 & 0.44 & 0.47 & 0.45 \\
CV (\%) & 8.61 & 10.22 & 9.43 & 7.33 & 8.25 & 7.22 & 9.4 \\
\hline
\end{tabular}

\section{C) Rice yield}

Grain yield of rice responded considerably by the adoption of nutrient and soil management treatments individually and combinedly (Table 7). The different soil management treatments had similar effect on rice yield until 2014. The soil management treatments were imposed in wheat and maize crops and the rice crop was transplanted in puddle flat soil condition for all the plots. The residual effect of soil management treatments on yield and of rice was non-significant until the $4^{\text {th }}$ year (2013). Mulches were applied twice a year and after the 4 years of mulch application, the residual effect of soil management became significant from 2015 and became more dominant with years (Table 7). Bed+Mulch gave higher yield than Bed and Flat+Mulch produced higher yield than Flat. Interactions of nutrient and soil management levels were significant for all the years (Table7).Due to interactions, the maximum grain yield $(5.86 \mathrm{t} / \mathrm{h})$ was obtained from the treatment combination of IPNS with Flat+Mulch that yield was closely followed by the yield obtained from IPNS with Bed+Mulch but higher than other combinations. Under any level of nutrients in the main plots the sub-plot treatments of Bed+Mulch and Flat+Mulch produced higher yield than respective non-mulch treatment with an exception in $\mathrm{RF}+\mathrm{CD}$ treatment. Under $\mathrm{RF}+\mathrm{CD}$ the different 
soil management treatments of Bed, Bed+Mulch, Flat and Flat+Mulch had produced statistically similar yield (Table7).

\section{D) Soil Nutrients}

The soil nutrient contents in post rice harvest soil samples analyzed after each cycle of cropping along with nutrient contents in initial soil are presented in Table 3 and Table 4. The analytical data indicated that due to triple cereal cropping for the six years, the soil organic matter $(\mathrm{OM})$ and all of the soil nutrient contents except $\mathrm{Zn}$ were depleted in plots under control (No fertilizer) compared to initial soil. On the other hand, the intensive triple cereal system did not cause the nutrient depletion in soils receiving IPNS treatment or $\mathrm{RF}+\mathrm{CD}$ treatment; further-more soil fertility of the plots receiving the aforementioned couple of treatments were improved with years (Table 3 and Table 4). Different soil management treatments had the similar effects on soil nutrients contents until the $2^{\text {nd }}$ cropping cycle and the impact of soil management treatments on soil nutrients contents became visible in $4^{\text {th }}$ cycle and thereafter dominant in $6^{\text {th }}$ cropping cycle. The treatment Bed+Mulch and Flat+Mulch resulted in higher $\mathrm{OM}$ and total $\mathrm{N}$ in surface soil than the respective non-mulch treatments. Also $\mathrm{K}, \mathrm{P}$ and $\mathrm{S}$ contents were varied in response to soil management levels and the treatment Flat+Mulch resulted in higher soil K, P and S contents. Zn content was also significantly higher in Flat+Mulch followed by Bed+Mulch. Soil Zn content was much high in plots receiving $\mathrm{RF}+\mathrm{CD}$ treatments compared to other nutrient levels. Soil B contents were similar for the different nutrient levels. The analytical report of cowdung indicated that cowdung contains sufficient $\mathrm{Zn}$ and $\mathrm{B}$ (Table 1c) thus the $\mathrm{Zn}$ enrichment was resulted from applied cowdung. Boron is known as very mobile in soil-water system, thus B enrichment in soil in response to cowdung application are uncommon but in the present experiment mulch application might have reduced the leaching loss of $\mathrm{B}$ that has led to increased $\mathrm{B}$ content in soil after $4^{\text {th }}$ cycle of cropping.

\section{Conclusions}

The long-term field research findings indicate that there are the potentials of integrating the maize crop in rice-wheat system if cowdung is used with recommended fertilizers and crop residue is used as mulch. Among the component crops in the system wheat and maize are responsive to higher level of fertilizers whereas rice gives higher yield under IPNS. Emphasis should be given for the promotion of the aforementioned cropping system with the integrated use of chemical fertilizer, organic manure and crop straw mulch. 


\section{References}

Gathala, M., J. K. Ladha, V. Balyan, Y. S. Saharawat, V. Kumar, P. K. Sharma, S. Sharma, and H. Pathak. 2011. Tillage and crop establishment affects sustainability of South Asian rice-wheat system. Amer. Soc. Agron. J. 103: 1-10.

Govaerts, B., K. D. Sayre., B. D. Goudeseune, P. Corte., K. Lichter, L. Dendooven and J. Deckers.2009. Conservation agriculture as a sustainable option for the central Mexican highlands. Soil and Tillage Res. 103: 222-230.

Gupta, R. and A. Seth. 2007. A review of resource conserving technologies for sustainable management of the rice-wheat cropping systems of the Indo-Gangetic plains (IGP). Crop Protection. 26: 436-447.

Gupta, R. and K. Sayre. 2007. Conservation agriculture in South Asia. Journal of Agricultural Science 145: 207-214.

Haque, M. A. and S. Noor. 2011. Long Term Integrated nutrient management for sustaining soil fertility and yield of Maize-Mungbean-T.Aman cropping pattern. 2011. Annual research report 2010-11, 78-83. Soil Science Division. Bangladesh Agricultural Research Institute, Gazipur.

Hossain, M. I., M. J. U. Sarker, and M. A. Haque. 2015. Status of conservation agriculture based tillage technology for crop production in Bangladesh. Bangladesh J. Agril. Res. 40(2), 235-248.

Jat, M. L., Y. S. Saharawat, and R. Gupta. 2011. Conservation agriculture in cereal systems of south Asia: Nutrientmanagement perspectives. Kar. J. Agric. Sci. 24: 100-105.

Qureshi, A. S., Z. U. Ahmad and T. J. Krupnik. 2015. Moving from Resource Development to Resource Management: Problems, Prospects and Policy Recommendations for Sustainable Groundwater Management in Bangladesh. Water Resources Management. 29: 4269-4283.

Rahman, M. A., J. Chikushi, M. Saifuzzaman and J. G. Lauren. (2005). Rice straw mulching and nitrogen response of no-till wheat following rice in Bangladesh. Field crops Research. 91: 71-81.

Rahman, M. A., N. C. D Barma and T. P. Tiwari. 2016. Triple cereal system with fertilizer and planting management for improving productivity in coastal saline soils of Bangladesh. Bangladesh J. Agri. Res. 41(1): 1-16.

Rahman, M. A., N. C. D. Barma, M. J. Uddin and T. P. Tiwari. 2013. Productivity of wheat-maize-rice cropping system shifted from conventional to conservation agricultural practices. In: Sustainable intensification of agriculture: Systems research helping to meet the needs and managing the trade-offs of changing world, Proceedings of the 4th International Symposium for Farming Systems Design. 19-22 August 2013, Lanzhou, China. pp. 145-147. Web: www.fsd2013.com

Rahman, M. A., N. C. D. Barma, T. P. Tiwari and J. G Lauren. 2011. Crop residue retention and nitrogen management to improve the productivity of no-till wheat following rice in Bangladesh. Proc. $5^{\text {th }}$ World Congress of Conservation Agriculture and $3^{\text {rd }}$ Farming System Design Conference. pp. 150-151.Sep 26-29, 2011 Brisbane, Australia. 
Sharma, P. K. and C. L. Acharya. 2000. Carry-over of residual soil moisture with mulching and conservation tillage practices for sowing of rain fed wheat (Triticumaestivum L.) in north-west India. Soil Tillage Res. 57: 43-52.

Timsina, J. and D. J. Connor. 2001. Productivity and management of rice-wheat cropping system: Issues and Challenges. Field Crops Res. 69: 93-132.

Timsina, J. and E. Humphreys. 2006. Performance of CERES-Rice and CERES-Wheat models in rice-wheat system: A review Agricultural systems.90: 5-31.

Timsina, J., M. L. Jat and K. Majumdar. 2010. Rice-maize systems of South Asia: current status, future prospects and research priorities for nutrient management. Plant Soil. 335: $65-82$.

Wall, P. C., A. Chocobar, J. Deckers and K. D. Sayre. 2010. Conservation agriculture, improving soil quality for sustainable production systems? In: Lal, R., Stewart, B.A. (Eds.), Advances in Soil Science: Food Security and Soil Quality. CRC Press, Boca Raton, FL, USA, ISBN: 9781439800577. pp. 137-208. 
